Island Studies Journal, Vol. 5, No. 1, 2010, pp. 61 - 88

\title{
From Incremental to Comprehensive: Towards Island-Friendly European Union Policymaking
}

Stefano Moncada

European Documentation and Research Centre

University of Malta, Malta

stefano.moncada@um.edu.mt

Marguerite Camilleri

Malta Environment \& Planning Authority, Malta

marguerite.camilleri@mepa.org.mt

Saviour Formosa

Institute of Criminology, University of Malta, Malta

saviour.formosa@um.edu.mt

and

Roberta Galea

Malta Environment \& Planning Authority, Malta

roberta.galea@mepa.org.mt

\begin{abstract}
The sustainability challenges faced by islands in the European Union (EU) are not well reflected in EU policy, where the approach to island issues has been incremental and fragmented. This paper identifies EU islands and their main sustainability issues, and argues for a stronger awareness of island issues in EU policy processes. It notes in particular the current restrictive definition of islands, which excludes island states, and the fact that the issues of peripherality and insularity do not fit into any of the categories provided in the EU's impact assessment guidelines. Moreover, since European islands are found at various administrative scales, there is a lack of harmonized statistical data on fundamental factors necessary for monitoring their sustainable development.
\end{abstract}

Keywords: European Union, impact assessment, insularity, islands, peripherality, sustainability

(C) 2010 - Institute of Island Studies, University of Prince Edward Island, Canada

\section{Introduction}

Sustainable development (SD) is a fundamental strategic objective of the European Union (EU) (CEC, 2001). However, the sustainability challenges faced by EU islands are not well reflected in EU policy, which has tended to be incremental as various types of islands became incorporated within the community, and fragmented by sector, with island policy featuring mostly in cohesion, agriculture and fisheries policy. This is despite the recognition that these regions face particular challenges due to their isolation and generally 
small size (Eurisles, 2002; Planistat, 2002; CEC, 1994), and which demand particular attention when operationalizing sustainable development. This is even more relevant since 2004 when two small island states, Cyprus and Malta, joined the EU.

In order to investigate these concerns, this paper first reviews the EU policy framework for island sustainability. It then identifies the location of EU islands based on a spatial dataset, and elaborates a set of European island sustainability issues that are identified through expert interviews. Since one of the principal tools for institutionalizing SD thinking within the EU policy process is the practice of impact assessment, the sustainability issues were then compared with the impact issues identified in the EU Impact Assessment Guidelines (CEC, 2005) $)^{1}$. In order to assess the dimensions of European island sustainability issues, these are then associated with a set of indicators, which are quantified and reviewed. The paper closes by identifying what needs to be addressed if EU policy is to reflect a stronger awareness of island sustainability concerns.

\section{EU Island Policy}

The EU has made special provisions for islands in its Treaty and a number of policies. Before reviewing these provisions, it is important to note that the EU generally distinguishes between three categories of islands: 1) islands that are whole or part of 'overseas countries and territories', such as Greenland, French Polynesia and Bermuda; 2) the group comprising the French overseas departments, the Azores, Madeira and the Canary Islands, often termed 'most remote regions', which it considers an inherent part of the EU, the distinctive characteristics of which qualify them for specific treatment in various sectors such as transport and cohesion policy under the Treaty of Amsterdam; and 3) continental EU islands, which are recognized under various sectoral polices such as agriculture and fisheries to be in need of special consideration.

With respect to the first category of islands, in its Part Four, the Treaty of Amsterdam specifically focused on the association with the Community of the non-European countries and territories that have special relations with Denmark, France, the Netherlands and the United Kingdom, as listed in Annex II to the Treaty. The purpose of association is described as promoting:

“... the economic and social development of the countries and territories ... to further the interests and prosperity of the inhabitants of these countries and territories in order to lead them to the economic, social and cultural development to which they aspire" (Article 182).

With respect to the second category of islands, the Treaty of Amsterdam made special reference to Europe's 'most remote regions': the French Overseas Departments of Guadeloupe, French Guiana, Martinique and Réunion, and to the Atlantic archipelagos of the Canaries, the Azores and Madeira. The special circumstances of these most remote regions are taken into account in Article 299:

\footnotetext{
${ }^{1}$ http://ec.europa.eu/governance/impact/docs/SEC2005 791_IA_guidelines_main.pdf.
} 
“... [h]owever, taking account of the structural, social and economic situation of the French overseas departments, the Azores, Madeira and the Canary Islands, which is compounded by their remoteness, insularity, small size, difficult topography and climate, economic dependence on a few products, the permanence and combination of which severely restrain their development, the Council ... shall adopt specific measures aimed, in particular, at laying down the conditions of application of the present Treaty to those regions, including common policies" (emphasis added).

With regard to the third category of islands - continental EU islands - relevant EU island policy is fragmented, and relates primarily to its cohesion, and agriculture and fisheries policies. EU cohesion policy makes special reference to islands and other regions with 'handicaps'. The preamble to Regulation 1080/2006, which lays out the rules for application of the European Regional Development Fund, indicates that this fund:

“ ... contributes to reducing the gap between the levels of development of the various regions and the extent to which the least favoured regions, including rural and urban areas, declining industrial regions, areas with a geographical or natural handicap, such as islands, mountainous areas, sparsely populated areas and border regions, are lagging behind" (emphasis added).

EU Regulation 1698/2005, which supports rural development via the European Agricultural Fund for Rural Development (EAFRD), indicates that special provisions should apply:

“... to mitigate the specific constraints and structural problems in farming and forestry activities and in adding value to agricultural and forestry products as a result of remoteness, insularity or distant location and of the dependency of the rural economy on a limited number of agricultural products, and to promote a robust rural development policy" (Article 60) (emphasis added).

In terms of fisheries policy, the Council Regulation 1198/2006 of 27 July 2006 on the European Fisheries Fund provides higher ceilings for outermost regions and outer Greek islands, which are described as "under a handicap due to distant location".

Meanwhile, all three categories of islands are addressed by a number of general provisions in the European Treaty. Article 154 of the Treaty of Maastricht (on Trans-European Networks) notes that the EU “... shall take account in particular of the need to link island, landlocked and peripheral regions with the central regions of the Community"; while Article 158 of the Treaty of Amsterdam (on cohesion policy) refers directly to the need to reduce the "backwardness of the least favoured regions", which includes islands.

This study focuses on the second and third category of EU islands, and does not consider the European overseas countries and territories that are far removed from the European continent and whose bio-geographical situation and thus sustainable development issues 
differ considerably from the islands within the European continent. Moreover, these islands are not members of the EU.

\section{Island Research}

European islands have attracted attention as areas of 'backwardness' (as noted in Article 158 of the European Treaty) within the EU policy community for a number of reasons, as also highlighted in the 2002 Eurisles publication Off the Coast of Europe, supported by the Conference of Peripheral and Maritime Regions (CPMR). This research reported that, although islands are diverse from one another, they share specific social, economic and environmental problems. These common issues represent various structural constraints that result in multiple consequences, such as a below average Gross Domestic Product (GDP) per capita and higher cost of living due to insularity. Small size of markets and weaker competition result in lower wages and reflect the lower living standards present on islands. The exceptional environment of islands is often threatened by the seasonality of the tourism industry and the vulnerability to climatic and seismic events, and environmental disasters. These vulnerabilities are compounded by other difficulties such as the fragmentation of territories due to archipelagic status, mountaineity and poor accessibility. The study also enters into the effectiveness or otherwise of EU polices with respect to islands and the impact of certain policies on European islands. Various studies show that EU state and regional aid and agricultural and fisheries assistance do not always favour islands because island dimensions are not always taken into consideration when it comes to planning or designing polices. Another element of concern is represented by the liberalization of transport services, particularly during the 1990s, which resulted in difficulties for island transportation networks.

The DG Regio-funded Planistat (2002) study on EU15 continental islands, as well as the Spanish African territories of Ceuta and Mellila, focuses on measures and policies undertaken by the EU and Member States to remedy any backwardness caused by being an island. Drawing on reports on island issues prepared by the European Parliament (EP, 1998), the Economic and Social Council (ECOSOC, 2000), and the Committee of the Regions (CoR, 2002) the study identified 15 island problems that characterize 'backwardness'. These include: isolation from the mainland, higher costs of sea and air transport, communications and infrastructure, restricted usable land area, limited fisheries resource, restricted water supplies, restricted sources of energy, marine and coastal pollution, difficulties in waste management, decreasing population, coastal erosion, the shortage of a qualified workforce, absence of a favourable economic climate for business, difficulties in access to health and education services, small size of local market, and poor economic diversification. The Planistat study concludes that EU policies can have impacts on islands in one of the following five ways: 1) by directly aiming at alleviating the problems of islands (cohesion and transport policies); 2) by applying across the whole EU with some limited territorial element (agriculture and fisheries, environment and cohesion fund); 3) by applying across the whole EU with little territorial element (competition and state aid); 4) by applying across the EU with no island priority but benefiting the islands (energy, research, information society, and public health); and, 5) within emerging areas of EU policy that may potentially assist the islands (employment - growing local dimension). 
Despite the special attention afforded to island concerns in the European Treaty and in cohesion, agriculture and fisheries policy, the EU approach to islands (if one can speak of one!) may be characterized as incremental rather than comprehensive, and fragmented across a number of policy areas. There is also the problem of definition, where the Eurostat (1994) working definition is now being used as a de facto definition of European island status when drawing up impact assessments, thereby excluding island states from being considered islands when the impacts of new policy proposals are being assessed (EC, 2006). It describes islands in terms of those geographical entities that are islands but $d o$ not host national capitals and are not linked to the mainland by a bridge. One positive development in this direction was the agreement achieved during the Intergovernmental Conference convening during the European Council of June 2007 (Conference of the Representatives of the Governments of the Member States, 2007) to clarify, in recognition of the specific challenges facing islands within the European territory, that the reference to island regions made in Article III-220 of the Draft Constitutional Treaty (IGC, 2004) also refers to island states.

After reviewing some of the conceptual issues related to the sustainable development of European islands, the methodology used in this research is then described. Next, the research findings are presented and discussed in the light of the selected sustainable development indicators identified for European islands. The conclusions summarize the research's major findings and outline directions for future research.

\section{Methodology}

The methodology used in this paper follows the SENSOR protocol established to carry out surveys in the four SENSOR sensitive regions, namely: coastal, post-industrial, mountainous and island.

\section{Geographical Identification}

A geographical identification of European (EU 25+3) ${ }^{2}$ islands based on a GIS operation ${ }^{3}$ that removed the European mainland, leaving only islands and island regions ${ }^{4}$ as the base set for consideration. Where it was known that islands are connected to the mainland with a bridge - as in the case of many Danish islands - these were removed from the dataset. The source of information about islands connected to their mainland with a bridge is the extensive Portrait of the Islands study published in 1994 by Eurostat, which however only covers EU12.

\footnotetext{
2 All EU member states at the time of the research (25), plus the three countries of the European Economic Area.

3 The basis of this calculation is the EuroGeographic NUTS0 data layer, which is the standard base map of the SENSOR project. Due to the specific use for which EuroGeographic created this aggregated base map, certain smaller islands are not included in the estimates.

${ }^{4}$ A small number of inland islands within lakes were generated as slivers through polygon combination error, and were manually cleansed from the dataset as far as this was possible.
} 


\section{Interviews on Sustainability Issues}

A literature review identified that firm conclusions with respect to sustainability issues in European islands remain lacking. The following assessment of secondary sources therefore indicated that primary data on sustainability issues would have to be gathered. This was done by interviewing 26 sustainability experts in a set of 28 representative study islands. This was conducted via telephone interviews with experts identified through the literature and various specialized networks, such as the (European) Islands Commission of the CPMR, Global Islands Network, and Eurisles. Experts were identified on the basis of their knowledge in the field of sustainability and/or expertise in relation to the islands that were the subject of the interview.

\section{Identification of Islands Study}

The Portrait of the Islands study (CEC, 1994) identified a set of some 450 inhabited islands that included all European islands that are not a host to a national capital and not linked to the mainland by a bridge. However, since this study was restricted to EU12, islands from the remaining 13 member states that joined after 1994 were considered. The island states of Malta and Cyprus were thus included, since these small island states experience island sustainability issues to an even higher degree than other islands due to lack of support, particularly of an economic nature, from a 'mainland'. However, island states such as Ireland and the UK, which are not considered as small island states at UN level (Hein, 2004) were not included in this survey as island states, although their islands were considered. Building on the above considerations, a set of study islands for detailed investigation was drawn up on the basis of the following criteria:

- For each of the EU $25+3$ countries that have islands, at least one major island or island group was included;

- Major European islands or island groups - in terms of population, size, high degree of political autonomy - were included (e.g. Sicily, Åland);

- A selection of both large islands and archipelagos were included (e.g. Sardinia, Crete, Balearics and Aegean);

- Islands from both northern and southern Europe were included, as well as those in the Atlantic, in order to ensure a balanced geographical distribution;

- Islands that are both close to the mainland (such as the Tuscan archipelago), as well as ones far from the mainland (e.g. Shetlands, Pantelleria).

$\underline{\text { Table } 1}$ below summarizes the selection made. 
Table 1: Selection of 28 Study Islands

\begin{tabular}{|c|c|c|c|}
\hline No & Country & Islands & Rationale for selection \\
\hline 1 & Cyprus & Cyprus & Small island state. \\
\hline 2 & Denmark & Bornholm & $\begin{array}{l}\text { Bornholm largest island with approximately } 45,000 \\
\text { people and an area of } 580 \mathrm{~km}^{2} \text {. The Faroe Islands, } \\
\text { also Danish, have not been selected due to the } \\
\text { presence of three other North Sea archipelagos in } \\
\text { selection. Greenland not included since not within } \\
\text { the European continental area. }\end{array}$ \\
\hline 3 & Estonia & Saaremaa & $\begin{array}{l}\text { The two principal Estonian Islands are Saaremaa } \\
\text { and Hiiumaa. Of these the larger island, Saaremaa, } \\
\text { which has an area of } 2,922 \mathrm{~km}^{2} \text { as opposed to } \\
\text { Hiiuma's } 1,023 \mathrm{~km}^{2} \text {, has been included in the study. }\end{array}$ \\
\hline 4 & \multirow[b]{2}{*}{ Finland } & Åland & \multirow{2}{*}{$\begin{array}{l}\text { Finnish Islands are made up of the Finnish Islands } \\
\text { archipelago and the Åland Islands, both of which } \\
\text { are included in the set of islands for the survey. }\end{array}$} \\
\hline 5 & & $\begin{array}{l}\text { Finnish Islands } \\
\text { Archipelago }\end{array}$ & \\
\hline 6 & France & Corsica & $\begin{array}{l}\text { French continental islands consist of Corsica, the } \\
\text { smallest of the French regions, }\left(8,681 \mathrm{~km}^{2}\right) \text { and } \\
\text { various small coastal islands on the Atlantic and } \\
\text { southern coasts.French overseas island territories } \\
\text { are not included since they are not part of the } \\
\text { European continent. }\end{array}$ \\
\hline 7 & Germany & East Frisian Islands & $\begin{array}{l}\text { The German islands are situated in the North Sea } \\
\text { and the Baltic Sea. Of the three archipelagos of the } \\
\text { East Frisian Islands, the islands of Schleswig- } \\
\text { Holstein and those of Mecklenburg-Vorpommern, } \\
\text { the East Frisian Islands have been included here. }\end{array}$ \\
\hline 8 & \multirow[b]{4}{*}{ Greece } & Crete & \multirow{4}{*}{$\begin{array}{l}\text { The largest island in Greece is Crete, with an area } \\
\text { of } 8,336 \mathrm{~km}^{2} \text { and a population of some } 550,000 \text {. } \\
\text { Greece also contains the archipelagos of the Ionian, } \\
\text { the Northern and Southern Aegean, and about } 40 \\
\text { small and medium-sized inhabited islets and islands } \\
\text { scattered around the Greek mainland. Crete and the } \\
\text { three archipelagos of the Ionian, the Northern } \\
\text { Aegean and Southern Aegean were selected. }\end{array}$} \\
\hline 9 & & Ionian & \\
\hline 10 & & Northern Aegean & \\
\hline 11 & & Southern Aegean & \\
\hline 12 & Iceland & Iceland & The island state of Iceland was selected. \\
\hline 13 & Ireland & Irish Islands & $\begin{array}{l}\text { Of Ireland's } 365 \text { islands, most of which are off the } \\
\text { west coast of Ireland, some } 53 \text { are inhabited. The } \\
\text { Irish islands were considered as a group and all } \\
\text { were included in the survey. }\end{array}$ \\
\hline & & & \\
\hline & & & \\
\hline
\end{tabular}




\begin{tabular}{|c|c|c|c|}
\hline 14 & \multirow[b]{4}{*}{ Italy } & Sicily & \multirow{4}{*}{$\begin{array}{l}\text { Italy's principal islands are Sicily and Sardinia, the } \\
\text { two largest islands in the Mediterranean. These } \\
\text { islands accounted for } 11 \% \text { of Italy's population in } \\
2002 \text {. Both were selected for this study. Italy also } \\
\text { contains various smaller archipelagos: the Tuscan } \\
\text { group, Ponziane Islands off Lazio, Gulf of Naples } \\
\text { islands, Tremiti archipelago in the Adriatic, and } \\
\text { smaller islands around Sicily and Sardinia. For this } \\
\text { study, the Tuscan archipelago and the remote island } \\
\text { of Pantelleria off southern Sicily were selected, in } \\
\text { order to address both issues of smaller archipelagos } \\
\text { and those of remote islands in the Mediterranean. }\end{array}$} \\
\hline 15 & & Pantelleria & \\
\hline 16 & & Tuscan Archipelago & \\
\hline 17 & & Sardinia & \\
\hline 18 & Malta & $\begin{array}{l}\text { Malta, Gozo and } \\
\text { Comino }\end{array}$ & $\begin{array}{l}\text { The island state of Malta with its sister islands of } \\
\text { Gozo and Comino were selected. }\end{array}$ \\
\hline 19 & Netherlands & West Frisian & $\begin{array}{l}\text { The seven West Frisian Islands of the Netherlands } \\
\text { were selected. }\end{array}$ \\
\hline 20 & Norway & Svalbard & $\begin{array}{l}\text { Norway consists of a large number of islands. } \\
\text { However the } 62,700 \mathrm{~km}^{2} \text { Svalbard archipelago, } \\
\text { Europe's northernmost territory, is relatively } \\
\text { remote from the mainland, and has been selected } \\
\text { here as an example of an Arctic archipelago. It lies } \\
\text { only } 1,000 \mathrm{~km} \text { from the North Pole and two thirds } \\
\text { of its land area is covered by glaciers. }\end{array}$ \\
\hline 21 & Portugal & Azores & $\begin{array}{l}\text { Portugal contains two island archipelagos: the } \\
\text { Azores }\left(9 \text { islands, } 1,527 \mathrm{~km}^{2}\right) \text { and Madeira }(4 \\
\left.\text { islands, } 797 \mathrm{~km}^{2}\right) \text {. Both of these are autonomous } \\
\text { regions with their own Parliamentary assemblies. } \\
\text { The larger archipelago of the Azores was selected } \\
\text { for the survey. }\end{array}$ \\
\hline 22 & \multirow[b]{2}{*}{ Spain } & Balearics & \multirow{2}{*}{$\begin{array}{l}\text { Spain's principal islands lie within the Balearic and } \\
\text { Canary archipelagos, both of which were selected. } \\
\text { Minor islands off Galicia in the North and Alicante } \\
\text { in the South were not included. }\end{array}$} \\
\hline 23 & & Canaries & \\
\hline 24 & Sweden & Gotland & $\begin{array}{l}\text { Sweden has numerous small islands; however } \\
\text { Gotland is the largest island with a land area of } \\
57,000 \mathrm{~km}^{2} \text { and a population of } 57,000 \text {. }\end{array}$ \\
\hline 25 & \multirow[b]{4}{*}{ UK } & Guernsey & \multirow{4}{*}{$\begin{array}{l}\text { The UK contains many islands and archipelagos, } \\
\text { from the Channel Islands (not part of the EU), Isles } \\
\text { of Scilly and Isle of Wight in the South; Isle of } \\
\text { Man in the Irish Sea; numerous Scottish islands and } \\
\text { archipelagos including Shetland, Orkney and Outer } \\
\text { Hebrides. To cover both northern and southern } \\
\text { British Isles, Guernsey, and the Outer Hebrides, } \\
\text { Orkney and Shetland Islands were included. }\end{array}$} \\
\hline 26 & & Outer Hebrides & \\
\hline 27 & & Orkney & \\
\hline 28 & & Shetland & \\
\hline
\end{tabular}




\section{Map 1: Visual identification of Study Islands (Source: MEPA, 2007)}

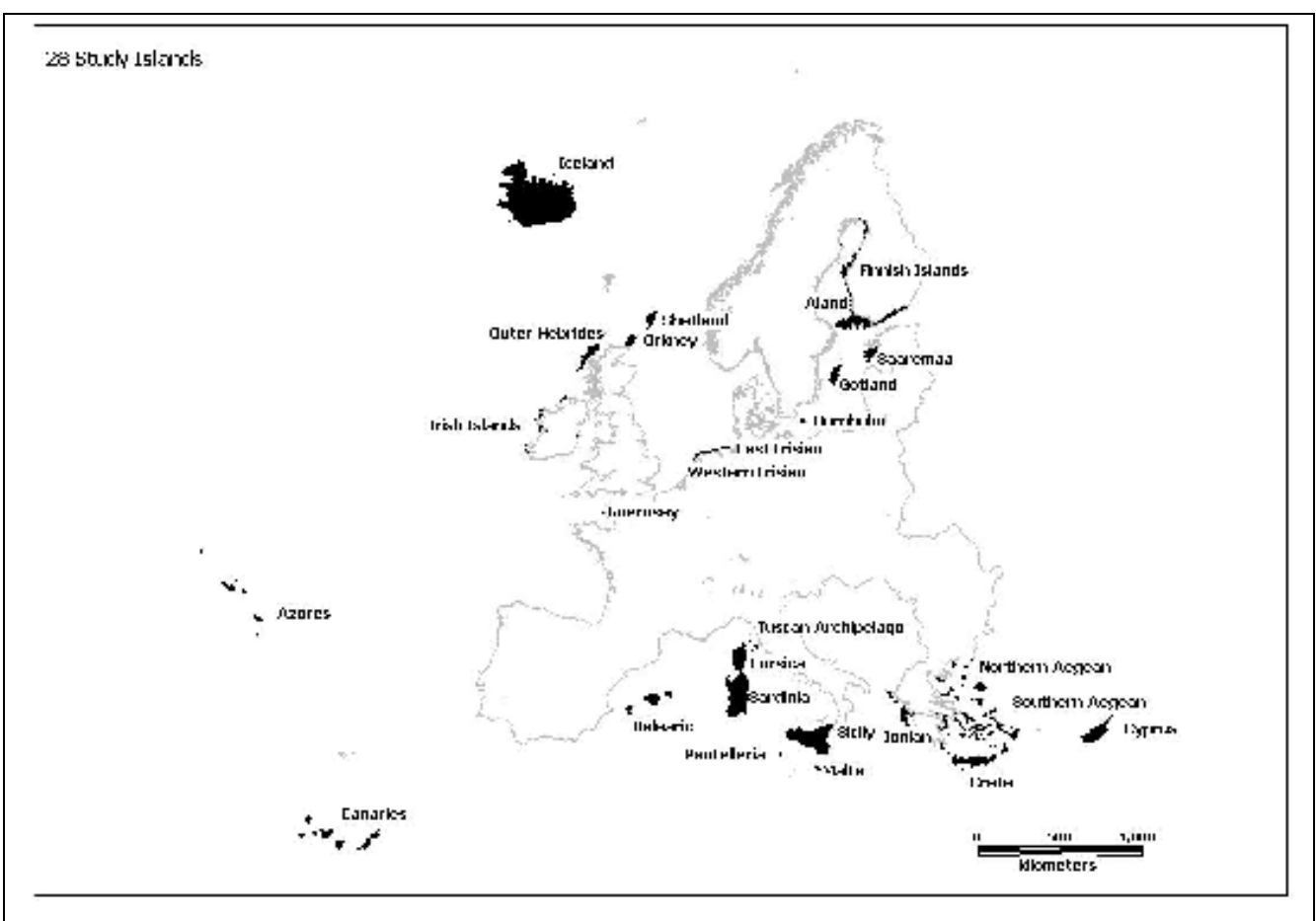

\section{Identification of Sustainability Indicators}

To discuss the sustainability issues identified, indicators of EU island sustainability were developed and quantified as far as possible. From the list of indicators ${ }^{5}$ already developed within the SENSOR project and based on the Impact Assessment Guidelines and from the indicators listed during the expert interviews, a list of 143 indicators was prepared. After a further assessment on the basis of specific criteria and a weighting exercise, 16 indicators that well described the sustainability concerns identified were selected. A spatial dataset based on these sustainability indicators was eventually developed.

\section{Clustering}

Cluster analysis was performed to identify relatively homogenous groups of islands or archipelagos within the set of 28 study islands, based on those sustainability indicators chosen through this survey that could be computed for a range of islands, ensuring that all three pillars of sustainability (that is, the economic, social and environmental) were addressed. Cluster analysis was performed by K-means and correlation analysis between the input variables was performed to exclude those less important variables that were intercorrelated with key indicators. Through this process, some of the variables were removed due to intercorrelation.

5 Draft indicator list produced by Module 2 of the SENSOR Project and available at: www.sensor-ip.org. 
Spatial statistical techniques were employed using CrimeStat's ${ }^{6}$ K-Means clustering procedure (Levine, 2002) that provides a great deal of control for the user and was used to identify 'hot spots' based on each variable. K-Means was deemed the best procedure for partitioning the variables under study into a small number of clusters. In this technique, each group is spatially assigned the best positioning of the $\mathrm{K}$ centres where each point is positioned to the centre that is nearest where all points are assigned to clusters. This procedure enables the visualization of those data points assigned to the nearest cluster.

\section{Results and Discussion}

This research has identified the position and extent of continental European (EU25+3) islands, as shown in Map 2. A total of 5,116 European islands, occupying a land area of $328,021 \mathrm{~km}^{2}$ or $6.76 \%$ of the area of EU25+3, were identified. In terms of all the countries of Europe (including those not in the EU), islands occupy 3.31\% of the land area. The identification of key sustainability issues, together with the construction of a dataset inclusive of the relevant sustainability indicators, shows that European islands face broadly similar challenges.

\section{Map 2: European Continental Islands across EU25 + 3}

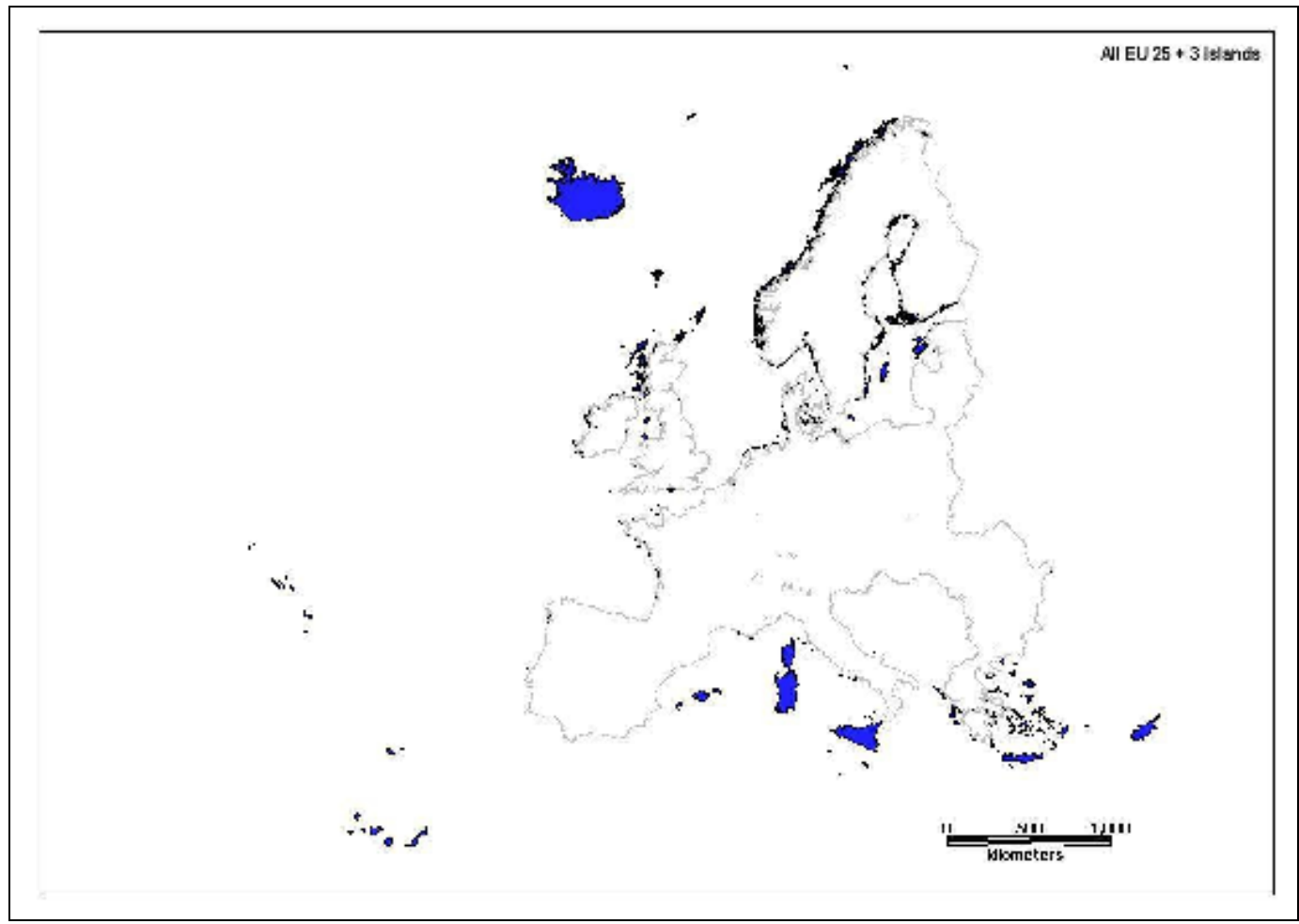

${ }^{6}$ CrimeStat is increasingly being used in the interpretation of social, environmental and physical disciplines as its technique is based on point analysis and facilitates spatial analytical research. 
As has been well documented (Planistat, 2002; Eurisles, 1997; 2002), European islands display a wide range of characteristics with respect to certain key indicators such as size, population, wealth and climate. However, this does not detract from the overall argument that islands exhibit particular common challenges related to problems of size, remoteness, status and isolation that deserve specific policy attention, including creating or extending policy related instruments, at EU and other scales. The 12 major issues that emerged from the 26 expert interviews are listed in Table 2 below.

Table 2: Sustainability Issues in European Islands, with Number of Mentions

\begin{tabular}{|c|c|}
\hline Key Issues & \\
\hline Issues with number of mentions & Islands where issues were mentioned \\
\hline 1. Extreme population dynamics (19) & $\begin{array}{l}\text { Aegean, Balearic, Bornholm, Corsica, Finnish } \\
\text { archipelago, Guernsey, Ionian, Irish islands, } \\
\text { Outer Hebrides, Svalbard }\end{array}$ \\
\hline $\begin{array}{l}\text { 2. Low potential for economic } \\
\text { diversification (16) }\end{array}$ & $\begin{array}{l}\text { Azores, Canaries, West Frisian, Guernsey, } \\
\text { Ionian, North Aegean, Orkney, Pantelleria, } \\
\text { Shetland, Tuscan archipelago }\end{array}$ \\
\hline $\begin{array}{l}\text { 3. Negative impact of land development } \\
\text { (16) }\end{array}$ & $\begin{array}{l}\text { Aegean, Åland, Balearic, Canaries, Cyprus, } \\
\text { East Frisian, Gotland, Malta, Outer Hebrides, } \\
\text { Pantelleria, Saaremaa, Tuscan archipelago }\end{array}$ \\
\hline 4. Marine Water Quality (13) & $\begin{array}{l}\text { Åland, Bornholm, Gotland, Finnish } \\
\text { archipelago, Iceland, Irish islands, Sicily, } \\
\text { Svalbard, Tuscan archipelago }\end{array}$ \\
\hline 5. Water Status (13) & $\begin{array}{c}\text { Aegean, Canaries, Finnish archipelago, } \\
\text { Gotland, Malta, Pantelleria, Sardinia, Sicily, } \\
\text { Tuscan archipelago }\end{array}$ \\
\hline $\begin{array}{l}\text { 6. Waste management challenges due to } \\
\text { small size and remoteness (12) }\end{array}$ & $\begin{array}{l}\text { Aegean, Azores, Cyprus, Corsica, Gotland, } \\
\text { Guernsey, Irish islands, Malta, Sardinia, } \\
\text { Shetland, Sicily, Tuscan archipelago }\end{array}$ \\
\hline 7. Tourism pressures (12) & $\begin{array}{l}\text { Balearic, Canaries, Finnish archipelago, East } \\
\text { Frisians, West Frisians, Gotland, Ionian, Malta, } \\
\text { Pantelleria, Sardinia, Sicily }\end{array}$ \\
\hline 8. Insularity and peripherality (10) & $\begin{array}{c}\text { Azores, Bornholm, Canaries, Cyprus, Malta, } \\
\text { Pantelleria, Sardinia }\end{array}$ \\
\hline 9. Declining agriculture and fisheries (9) & $\begin{array}{l}\text { Bornholm, Corsica, Cyprus, Finnish } \\
\text { archipelago, Irish islands, Orkney }\end{array}$ \\
\hline
\end{tabular}




\begin{tabular}{|c|c|}
\hline $\begin{array}{c}\text { 10. Degradation of natural resources and } \\
\text { loss of biodiversity (8) }\end{array}$ & $\begin{array}{c}\text { Iceland, Irish islands, Malta, Pantelleria, } \\
\text { Saaremaa, Sardinia, Svalbard }\end{array}$ \\
\hline $\begin{array}{c}\text { 11. High cost and impact of energy use } \\
(7)\end{array}$ & $\begin{array}{c}\text { Balearic, Gotland, Irish islands, Malta, } \\
\text { Shetland, Sicily }\end{array}$ \\
\hline 12. Low levels of education and training & Aegean, Azores, Malta \\
\hline 13. Other issues (2 or more) & $\begin{array}{c}\text { Climate change (4); Unemployment (3); } \\
\text { Transport (2); Air pollution (2); Poor } \\
\text { infrastructure (2); Coastal protection (2) }\end{array}$ \\
\hline
\end{tabular}

\section{Impact Assessment Guidelines and Sustainability Issues in EU Islands}

This section addresses the relevance of the EU impact issues contained in the Impact Assessment Guidelines (CEC, 2005) in relation to European islands. Table 3 (a-c) places each of the key island sustainability issues in the context of the EU impact issues, indicating that these are indeed general enough to cover all island issues. However, it also shows that some of the key island issues such as peripherality and competitiveness vis-àvis the European mainland are only indirectly addressed. In terms of assessing the impacts of policy on sustainable island development, this is an important finding, suggesting that insularity and peripherality could be added to the list of impact issues.

Table 3a: Comparison of Key Sustainability Issues for Islands with EU Impact Issues (Economic)

\begin{tabular}{|c|c|}
\hline Impact issue & Key Sustainability Issue for EU Islands \\
\hline $\begin{array}{c}\text { ECO1: Competitiveness, trade and } \\
\text { investment flows }\end{array}$ & $\begin{array}{c}\text { Extreme population dynamics, Low potential } \\
\text { for economic diversification }\end{array}$ \\
\hline ECO2: Competition in the internal market & $\begin{array}{c}\text { Extreme population dynamics, Low potential } \\
\text { for economic diversification, Declining } \\
\text { agriculture and fisheries }\end{array}$ \\
\hline bCOsiness & $\begin{array}{c}\text { Extreme population dynamics, Low potential } \\
\text { for economic diversification }\end{array}$ \\
\hline ECOninistrative costs on businesses & $\begin{array}{c}\text { Extreme population dynamics, Low potential } \\
\text { for economic diversification, Waste } \\
\text { management challenges due to small size and } \\
\text { remoteness }\end{array}$ \\
\hline ECO6: Innovation and research & Low levels of education and training \\
\hline ECO7: Consumers and households & High costs and Impacts of Energy use \\
\hline ECO8: Specific regions or sectors & Insularity and peripherality \\
\hline $\begin{array}{c}\text { ECO9: } \text { Third countries and international } \\
\text { relations }\end{array}$ & N/A \\
\hline
\end{tabular}




\begin{tabular}{|c|c|}
\hline ECO10: Public authorities & $\begin{array}{c}\text { Waste management challenges due to small } \\
\text { size and remoteness, High costs and impacts of } \\
\text { energy use }\end{array}$ \\
\hline ECO11: The macroeconomic environment & Low potential for economic diversification \\
\hline OTHER economic issues & N/A \\
\hline
\end{tabular}

Table 3b: Comparison of Key Sustainability Issues for Islands with EU Impact Issues (Social)

\begin{tabular}{|c|c|}
\hline Impact issue & $\begin{array}{c}\text { Key Sustainability Issue for EU } \\
\text { Islands }\end{array}$ \\
\hline SOC1: Employment and labour markets & Tourism pressures \\
\hline SOC2: Standards and rights related to job quality & Tourism pressures \\
\hline $\begin{array}{c}\text { SOC3: Social inclusion and protection of particular } \\
\text { groups }\end{array}$ & $\begin{array}{c}\text { High costs and impacts of energy } \\
\text { use }\end{array}$ \\
\hline $\begin{array}{c}\text { SOC4: Equality of treatment and opportunities, non } \\
\text { - discrimination }\end{array}$ & N/A \\
\hline SOC5: Private and family life, personal data \\
$\begin{array}{c}\text { SOC6: Governance, participation, good } \\
\text { administration, access to justice, media and ethics }\end{array}$ & Tourism pressures \\
\hline SOC7: Public health and safety & $\begin{array}{c}\text { Insularity and peripherality, Tourism } \\
\text { pressures }\end{array}$ \\
\hline SOC8: Crime terrorism and Security & Tourism pressures \\
\hline $\begin{array}{c}\text { SOC9: Access to and effects on social protection, } \\
\text { health and educational systems }\end{array}$ & Insularity and peripherality \\
\hline OTHER social issues & N/A \\
\hline
\end{tabular}

Table 3c: Comparison of Key Sustainability Issues for Islands with EU Impact Issues (Environmental)

\begin{tabular}{|c|c|}
\hline Impact issue & Key Sustainability Issue for EU Islands \\
\hline ENV1: Air quality & $\begin{array}{c}\text { Negative impact of land development, High } \\
\text { costs and impacts of energy use }\end{array}$ \\
\hline ENV2: Water quality and resources & Tourism pressures \\
\hline ENV3: Soil quality or resources & $\begin{array}{c}\text { Declining agriculture and fisheries; Degradation } \\
\text { of natural resources and loss of biodiversity; } \\
\text { Negative impact of land development }\end{array}$ \\
\hline ENV4: The Climate & $\begin{array}{c}\text { Marine water quality, High costs and impacts of } \\
\text { energy use }\end{array}$ \\
\hline $\begin{array}{c}\text { ENV5: Renewable or non-renewable } \\
\text { resources }\end{array}$ & $\begin{array}{c}\text { Declining agriculture and fisheries; Degradation } \\
\text { of natural resources and loss of biodiversity, } \\
\text { Marine water quality, Negative impact of land } \\
\text { development, High costs and impacts of energy } \\
\text { use }\end{array}$ \\
\hline
\end{tabular}




\begin{tabular}{|c|c|}
\hline $\begin{array}{l}\text { ENV6: Biodiversity, flora, fauna and } \\
\text { landscapes }\end{array}$ & $\begin{array}{c}\text { Degradation of natural resources and loss of } \\
\text { biodiversity, Negative impact of land } \\
\text { development, Marine water quality }\end{array}$ \\
\hline ENV7: Land use & $\begin{array}{l}\text { Negative impact of land development, Tourism } \\
\text { pressures, Waste management challenges due to } \\
\text { small size and remoteness, High costs and } \\
\text { impacts of energy use }\end{array}$ \\
\hline $\begin{array}{l}\text { ENV8: Waste production / generation / } \\
\text { recycling }\end{array}$ & $\begin{array}{c}\text { Waste management challenges due to small size } \\
\text { and remoteness, Negative impact of land } \\
\text { development Tourism pressures }\end{array}$ \\
\hline $\begin{array}{l}\text { ENV9: The likelihood or scale of } \\
\text { environmental risks }\end{array}$ & $\begin{array}{l}\text { Marine water quality, High costs and impacts of } \\
\text { energy use }\end{array}$ \\
\hline $\begin{array}{l}\text { ENV10: Mobility (transport modes) and } \\
\text { the use of energy }\end{array}$ & $\begin{array}{l}\text { Insularity and peripherality, High costs and } \\
\text { impacts of energy use }\end{array}$ \\
\hline $\begin{array}{l}\text { ENV11: The environmental consequences } \\
\text { of firms' activities }\end{array}$ & $\begin{array}{l}\text { Tourism pressures, Waste management } \\
\text { challenges due to small size and remoteness, } \\
\text { High costs and impacts of energy use, }\end{array}$ \\
\hline $\begin{array}{l}\text { ENV12: Animal and plant health, food and } \\
\text { feed safety }\end{array}$ & Marine water quality. \\
\hline OTHER environmental issues & Declining agriculture and fisheries \\
\hline
\end{tabular}

\section{Sustainability Indicators for EU Islands}

In order to be able to discuss island sustainability issues in more depth and comparatively, a set of sustainability indicators has been developed. This list was based on indicators suggested by interviewees and proposed by the SENSOR project to correspond with the EU impact issues as defined in its Impact Assessment Guidelines (CEC, 2005). Table 4 presents the final list of indicators for island sustainable development. Although data availability in some cases was relatively poor, two indicators ('\% land covered by Natura 2000 sites' and 'Compliance with Bathing Water Directive'), were left in the set as they related to highly significant issues which could not be better covered by another indicator. In two cases where data was difficult to access, surrogate indicators were used, although they addressed the issue less well.

The indicators were then quantified with data being collected primarily from such international databases as those of Eurostat and the European Environment Agency. In some cases, coverage was thin, such as when data was only available at NUTS-2 level and therefore, had to be supplemented by data from island statistical publications. This was however avoided as much as possible, in order to avoid comparability issues. The spatial coverage of certain datasets is therefore not wide. Full coverage was only obtained for data available in raster (data presentation) format, such as the Integrated Pollution Prevention and Control (IPPC) precipitation data and the European Environmental Agency (EEA) and Indicator Reporting on the Integration of Environmental Concerns into Agriculture Policy (IRENA) water extraction for agriculture data, where values could be collected for small geographical regions. Comparable datasets for indicator 14 (Table 4) on Natura 2000 sites could not be located at the required scale. However, this will be eventually available when 
these sites are approved at EU level. A major finding of this survey, therefore, which echoes the concerns raised in Planistat (2002) and Eurisles (2002), deals with the need to develop comparable datasets on sustainability issues, which may be used to inform policy decisions at EU level regarding sustainable development in island regions.

\section{Table 4: Final list of 16 Sustainable Development Indicators for EU25+3 Islands}

\begin{tabular}{|c|c|c|c|}
\hline No & Indicator Name & Proxy & $\begin{array}{c}\text { Issue } \\
\text { No }\end{array}$ \\
\hline 1 & Population density & 1 \\
\hline 2 & \% of population above 65 years & & 1 \\
\hline 3 & Employment by sector & & 2 \\
\hline 4 & Unemployment rate & 2 \\
\hline 5 & GDP per capita (EURO/National currency) & & 2 \\
\hline 6 & \% land built up & $\begin{array}{c}\text { \% urban area of total } \\
\text { (CORINE) }\end{array}$ & 3 \\
\hline 7 & \% Compliance with Bathing Water Directive & & 4 \\
\hline 8 & Water extraction rate (ground and surface) & $\begin{array}{c}\text { Water extraction rate } \\
\text { for agriculture } \\
\text { (IRENA) }\end{array}$ & 5 \\
\hline 9 & Precipitation rate & & 5 \\
\hline 10 & Municipal waste generation per capita & & 6 \\
\hline 11 & Daily tourist population per km ${ }^{2}$ & & 7 \\
\hline 12 & $\begin{array}{c}\text { Virtual distance from centre of Europe } \\
\text { (Eurisles study) }\end{array}$ & & 8 \\
\hline 13 & \% agricultural land use change & & 10 \\
\hline 14 & $\%$ of land covered by Natura 2000 sites & & 11 \\
\hline 15 & Energy consumption per resident population & & 12 \\
\hline 16 & $\%$ of researchers in relation to active & & \\
\hline
\end{tabular}

\section{Clustering}

Once the island sustainability indicators had been quantified, a clustering exercise was carried out to identify areas across EU $25+3$ of greater concern. As noted above, correlation analysis was carried on the 15 quantified variables, in order to ensure their mutual independence. Out of the 15 variables, six (6) resulted as independent, and the remainder could not therefore be considered for inclusion in the list of clustering variables. First, all five variables - relating to 'population above 65 years', GDP per capita, sectoral employment ('\% services in total employment'), research density and precipitation rate were removed since they all correlated positively with unemployment rate. Next, modest positive correlations were found between ' $\%$ urban land use' and 'population density', 'energy consumption per resident population' and 'municipal waste generation per capita'. Finally, there was a strong negative correlation between '\% agricultural land use change' and 'unemployment rate' and a slight negative correlation between bathing water quality and energy consumption. 
And so, the following independent variables were used in the cluster analysis: population density; unemployment rate; water extraction rate; daily tourist population per $\mathrm{km}^{2}$; energy consumption per capita; and virtual distance from the centre of Europe (symbolized by Maastricht).

Based on the geographic separation between the North and South island groups, the procedure was expected to produce different clusters for these regions, with the production of multiple clusters in both areas. This was not the case, however, since only two clusters emerged strongly, those designated as representing Northern and Southern Europe. Smaller clusters within each were not produced even when a minimum number of four clusters were forced. This is due to the relatively small differentiation between the islands in each group, such that no higher-level clustering is possible. The results show that spatial clustering procedures such as K-Means analysis serve to highlight potential hotspots that deserve further study.

The limitations of clustering on such small datasets, which may be skewed in favour of the more politically prominent islands of Southern Europe (which have higher NUTS classifications, and thus better data availability) is acknowledged. Nevertheless, on the basis of the six sustainability indicators utilized out of the 16 originally proposed, two clusters, with a stronger one in the South, emerge, as shown in Map 3.

Map 3: Geographical clusters where sustainability issues predominate in 28 study islands

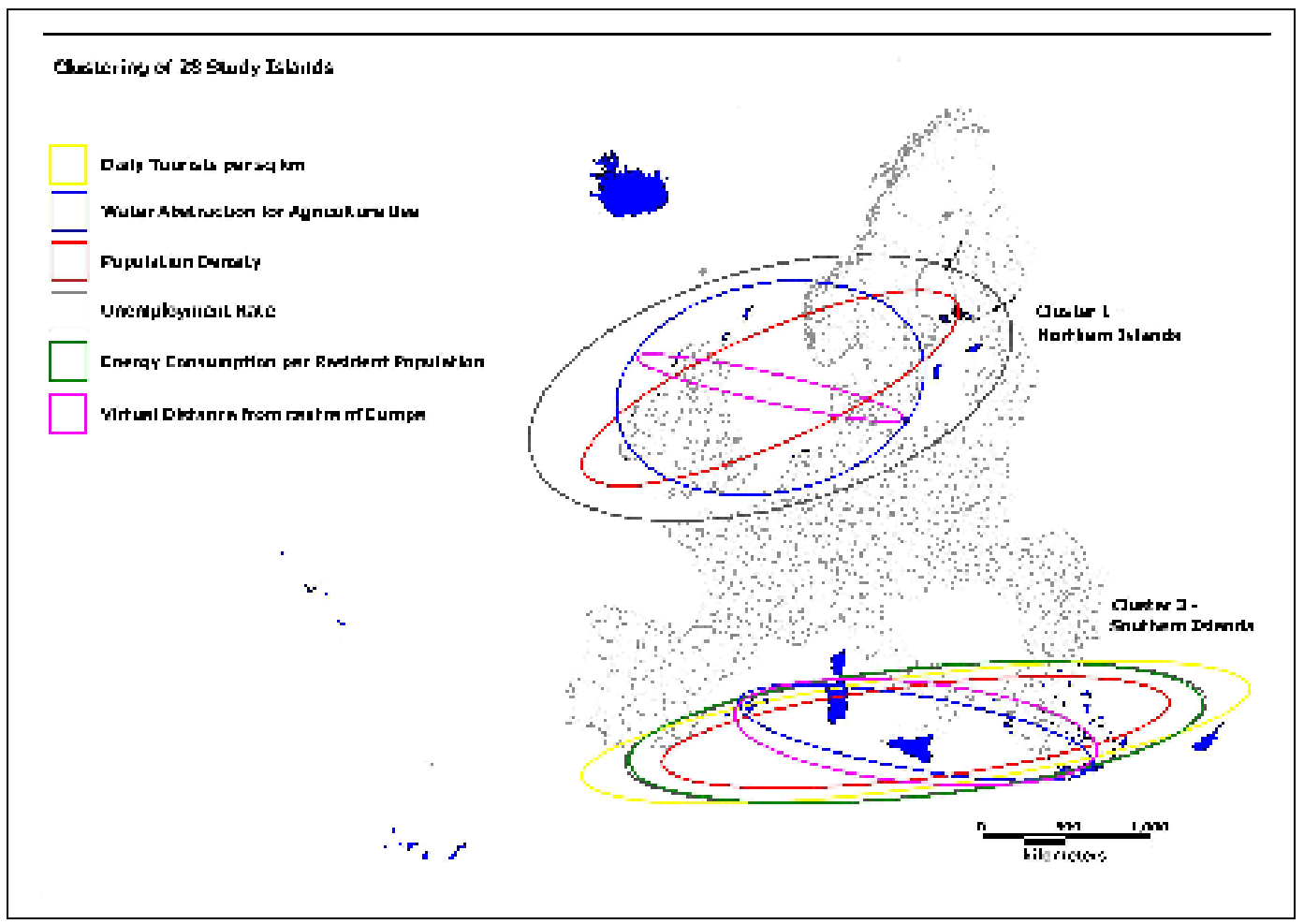


Two clusters emerge strongly, in Northern and Southern Europe. For two indicators, 'daily tourists per square kilometre' and 'energy consumption per capita', clusters did not appear in Northern Europe, whereas strong clusters around these issues emerged in the South. In the case of the energy variable, however, this is probably due to the poor data coverage in Northern Europe, where Eurostat NUTS-2 data only provided a figure for Åland.

These findings were used to identify a case study area within the final phase of the SENSOR project. The island state of Malta was selected as a sensitive area case study (SAC) because it lies at the centre of the Southern Islands cluster, which was characterised by higher rates of clustering for all the six variables identified.

\section{Sustainability Issues in EU25+3 islands}

This section examines each key issue raised by expert interviewees, drawing on the sustainable development indicators developed and quantified in this survey to better understand their scale, scope and severity.

\section{Extreme Population Dynamics}

Extreme population dynamics was a recurrent subject raised during the expert interviews. Population, in general, is an issue that is invariably linked with the sense of belonging to a community and to a territory. Population density may vary substantially among islands and may relate to both concerns over high and low densities. Low density is often associated with depopulation, out-migration and the consequent problems of brain drain, aging population and concerns about sustainability of the social budget and of the economy (this was the case in Corsica, the Finnish Archipelago, the Irish Islands, Outer Hebrides, Bornholm, Southern and Northern Aegean, Guernsey). The issues associated with an ageing population were often mentioned by respondents.

Maintaining the population, often small, with an adequate presence (and quality) of services is also a major concern, given that citizens might be forced to travel significant distances to receive, say, medical treatment or enjoy educational facilities. The latter is particularly evident in the Southern and Northern Aegean Islands, and in the Ionian and Irish Islands. Many islands, on the other hand, experience very high levels of population density, manifesting severe environment capacity stresses as well as high levels of social concern related to issues such as land use and immigration.

The Maltese Islands have the highest population density with 1,263 persons per $\mathrm{km}^{2}$, Guernsey with 807 persons per $\mathrm{km}^{2}$, the Canary Islands with 248 persons per $\mathrm{km}^{2}$, Sicily registering 196 persons per $\mathrm{km}^{2}$ and the Balearic Islands with 184 persons per $\mathrm{km}^{2}$, compared to the EU average of 117 . Malta is the most densely populated country in Europe and the third densest in the world. In this context a special reference has to be made to the growing influence, not only numerical, of immigrant communities in European 
islands. This phenomenon is not exclusively European and does not influence only islands, but the implications for islands are perceived, and objectively appear, more serious. Small densely populated islands subjected to high immigration pressures often experience a dramatic change in the structure of their populations, posing social challenges with respect to cultural and religious identities and as well as logistical and financial ones.

In many islands, as in many European countries, the phenomenon of gentrification was noted, where the process of physical renovation of declining neighbourhoods that brings an increase in property values, favours an influx of wealthier residents who, by out-pricing the local residents, displace the island's original inhabitants from their home.

\section{Low Potential for Economic Diversification}

Respondents recognized the difficulty of achieving sustainable economic performance within the context of a fragile reliance on only one driving economic sector. This issue is characterized by the dominance of the oil industry in the Orkneys, financial services in Guernsey and tourism in most of the Mediterranean islands. Interestingly, policy communities seem to be aware of the potential dangers caused by the lack of diversification in the economy; sustainable economic and land-use planning was one of the major policy solutions recommended during the interviews.

\section{Negative Impact of Land Development}

Land use and tendencies towards excessive development are major concerns in many islands. Urbanization rates across EU islands are varied and generally higher in islands experiencing stronger tourist pressure. Pressure from developers in order to either boost tourism activities or enlarge the property market occurs across islands from the Baltic (Saaremaa) and the Mediterranean (Balearics, Pantelleria and Malta) to the North Sea (East Frisians) and the Atlantic Ocean (Outer Hebrides). Coupled with this there is the recognition that the form of land-use planning as currently practised may not be sufficient to address the proper management of present and future development. Strictly related to this there is also a concern related to extensive quarrying activity, where the Aegean Islands, Gotland and Malta registered particular concern. The important role of the construction sector in island economies is also a challenge, particularly in relation to its impacts on the environment in the Canaries, Aegean Islands, the Balearics and Malta.

\section{Marine Water Quality}

Sea water quality emerged as an important consideration, given that inshore marine waters perform vital functions and services for islands. This concern was not of an ecological nature only because, for the majority of the islands, the sea is also associated with tourism. Maintaining an adequate level of marine protection is therefore vital to preserve a high degree of competitiveness and consequently acceptable levels of employment. Sea pollution, sewage discharges, the extensive presence of fish farms, and other marinerelated issues were raised during the interviews. The international aspects of the protection of marine areas were also highlighted, together with an extended concern associated with 
potential damages caused by climate change and sea level rise. This is more evident in islands like Iceland and Svalbard, where ice melt and trans-boundary pollution considerably impact on their environment and economy.

European legislation, particularly the Bathing Water Directive and the Water Framework Directive, plays an important role in the protection of the sea. It is generally agreed that the directives and regulations during last decades have brought positive improvements, although results in the more remote islands are not very visible. Considerable difficulty was registered in gathering information on marine water quality, particularly because thresholds and parameters are often not tailored to islands' sizes and characteristics. With respect to the compliance with the Bathing Water Directive in 2005, almost all the islands comply with the requirements.

\section{Water Status}

European island experts identified water scarcity and sustainable use of this important resource as crucial concerns. There is wide recognition that water plays a crucial role in environmental, social and economic aspects of island communities. In addition, contamination of ground water from polluting agricultural activities was also an issue (particularly in the Canary Islands, Sardinia, Malta and Gotland), together with illegal and uncontrolled water extraction. The extraction rates for agriculture indicate that water pressures are greater in southern Europe, where precipitation rates are lower, as might be expected. Given these considerations, the need for better management and regulation of water resources emerged as one of the most recurrent concerns.

\section{Waste Management Challenges Due to Small Size and Remoteness}

The problems associated with waste management invariably arose for most of the islands studied. Higher levels of consumption and consequently larger amounts of waste produced, in relation to land, was a common theme. Limited land area for storage of waste, and environmental and social problems associated with the location of landfills, were major concerns within island communities. The challenges related to waste recycling in small islands were also raised by numerous respondents. The waste to energy issue was also raised on a number of occasions. The difficulty with collecting large quantities of waste to recycle (due to limited land and small catchment areas for waste collection), does not allow small and medium size islands to benefit from economies of scale.

The costs associated with the construction and maintenance of waste recycling plants and the high costs of transport of final products (shipping and air freight), together with markets too small to absorb the amount of products which make this process worth investing in, constrain recycling activities and the development of alternative environmental options. 


\section{Tourism Pressures}

Many interviewees (12) expressed major concerns with the pressure on the islands represented by tourism. Although tourism represents an important part of islands' income, the negative consequences represented by high consumption of energy, water and land for the creation of adequate infrastructures and facilities were often raised. The pressure represented by the presence of tourists in the islands is further aggravated by population density. This is particularly true for highly densely populated islands and for islands that receive a high number of tourists throughout the year. Those islands - including Canaries, Balearics and Malta - which already have a relatively high population density, experience an even higher density when the tourist population is also considered.

In some islands, the short tourist season presents an additional pressure on the territory and its resources. Coupled with this there is the necessity to manage tourism activities better and to set strategies to concretely incorporate sustainability concerns within tourism planning.

\section{Insularity and Peripherality}

Due to their insularity and peripherality, islands have certain characteristics that distinguish them from continental regions. From an economic point of view, growth is strongly influenced by the limitations of natural resources and the dependency on imports. This significantly affects the efficiency of the local economy, which leads to greater vulnerability.

From an ecological perspective, the isolation from continental areas and their relatively small size determine a greater diversity in their ecosystems. On the other hand, these conditions create a scenario where the impacts are both more intense and more noticeable due to the fact that the capacity for auto-regeneration in insular systems is far weaker.

Higher costs of transport and greater difficulties to reach the islands, compared with the mainland, are also of great concern among island communities, and this concern has reached the policy level as reflected in the 2002 EU Treaty.

\section{Declining Agriculture and Fisheries}

Agricultural and fisheries activities have always played an important role in European islands. Both the physical presence of the related facilities and the culture and traditions associated with these activities remain important for island communities. However, agriculture and fisheries are experiencing either a decline in productivity, with less production and lower levels of employment, or a radical change from extensive to intensive production, changing the structure of the activity, often with the creation of negative environmental externalities. Within this context, the decline has a negative effect on the economy as well as drives environmental change in the form of land abandonment, landscape degradation and loss of fish stocks and biodiversity, including agro-biodiversity. 


\section{Degradation of Natural Resources and Loss of Biodiversity}

Loss of biodiversity and the need for improved nature protection are very important concerns that have been highlighted by the interviewees and the existing literature on European islands (Tyndall, 2005; Eurisles, 2002). The potential loss of the very specific and unique biodiversity of islands is one of the most frequent issues mentioned with the main concerns arising from Saaremaa, Malta, Svalbard and Pantelleria. Protection of nature against development (such as wind farms, industrial plants and major development projects) is a common preoccupation in islands. This is particularly so in the Shetlands and the West Frisians, where plans to develop wind farms have raised several questions regarding impact on landscape and disturbance of local fauna. Indeed, the fear of losing the islands' natural assets because of unsustainable physical land development is a major concern. Islands' dependency on natural resources, and the potential dangers that this process implies, were often noted.

The expansion of aquaculture arose as a common concern, together with its consequences on quality of the sea and food safety. In addition to this, there is a certain apprehension about how to ensure that traditional fishing and agricultural practices remain viable, both economically and socially.

\section{High Cost and Impact of Energy Use}

Energy-related issues represent a matter of common concern for European islands, with excessive consumption, collectively or by sectors, recognized as a serious problem. This is particularly true for those islands that rely on fossil fuels and do not have adequate facilities to store oil. The dependency on fossil fuels is critical, both as a strategic issue and because of the negative implications for the environment and health.

The necessity to switch to alternative energy provision, which would be less dependent on foreign supply and is less polluting, was recognized as a priority for European islands. On the other hand, many of the islands identified are currently facing tensions between landscape concerns and the need to install large scale alternative energy technology. Although the need to diversify the production of energy was recognized as extremely important and generally found the support of interviewees, the impact of these large plants on the landscape remains of great concern in many island communities.

\section{Low Levels of Education and Training}

Issues related to adequate levels of education and training also emerged as matters of concern. Lack of quality in human resources, understood in terms of the necessity to search outside the islands' work forces to fill jobs and positions, presented a challenge to many islands. The phenomenon of travel to learn was also raised as one of the consequences of lack of adequate academic facilities and/or opportunities. Coupled with this there is the problem of 'brain drain', where a consistent segment of the skilled and educated workforce leaves the islands to take up work opportunities that would have not been available locally. In fact, the percentage of researchers living and operating in European islands is often low. 
There is an exception in the case of Iceland, which has consistently invested in education and has a level of research that significantly exceeds the EU average (Baldacchino \& Milne, 2000).

\section{Island Issues in EU Policy following 2004}

As part of this research, the authors have also assessed whether the accession of island states to the EU has had a bearing on the way island issues have been addressed within EU policy-making. Besides the obvious example of the way islands have been included as sensitive areas within policy research (such as the SENSOR project on which this study is based), policy outcomes have also been examined.

It emerges that, following the accession in 2004 of Malta and Cyprus, two small island states, the specific concerns faced by islands have progressively gained more importance within the EU policy arena. In many instances, the particular characteristics of islands have been incorporated within EU legislation. This is the case for Directive 2008/101, which deals with the inclusion of aviation activities in the scheme for greenhouse gas emission allowance trading within the Community. In this specific case, following pressures during the negotiations from the Maltese counterpart, an Article (f) was included, referring to the need for the Commission to review by 2014 the functioning of the directive in relation to aviation activities. This article established that this review exercise would be undertaken by giving consideration to 'the impact of the Community scheme on the structural dependency on aviation transport of islands, landlocked regions, peripheral regions and the outermost regions of the Community'.

An additional area where European islands, particularly Southern Mediterranean islands, have influenced EU policy is the common immigration policy, primarily over illegal migration. In this specific policy area, European island states have tried to influence EU's common immigration policy both in the EU Council and in the European Parliament (EP Busuttil, 2009a). One of the requests (coming from Malta) was for the introduction of a burden sharing mechanism (EP - Busuttil, 2009b; 2009c), whereby small or less equipped states experiencing large number of migrants landing on their shores, would receive help and assistance by the EU, both in terms of patrolling (the 'Frontex' initiative) and active assistance on site. In addition to this, Malta has successfully managed to finalize a relocation agreement for some migrants landed on its shores to those other EU member states which had voluntarily agreed to offer specific assistance to Malta on this specific concern. Malta has also received over $€ 30$ million EU funds for immigration since it joined the EU in 2004 and more funds have already been allocated for the financial period ending in 2013. It is interesting to note that, although the initial amount of funds in the early years of accession were substantially low, in the region of $€ 1,8$ million in 2004, in the following years the total funds grew exponentially, for a total forecasted of $€ 112$ million in 2010 (EP, 2009). Malta's political pressure towards the EU institutions to intervene over immigration issues has certainly intensified, with higher numbers of immigrant arrivals and growing domestic tensions on how to manage integration of migrants in its territory and culture. 


\section{Conclusion}

The European islands occupy a land area of 0.3 million $\mathrm{km}^{2}$ or $6.76 \%$ of the area of EU25+3. In terms of all the countries of Europe (including those not in the EU), islands occupy $3.31 \%$ of the land area. The identification of key sustainability issues, together with the construction of a dataset inclusive of the relevant sustainability indicators, shows that European islands face a set of fairly similar challenges.

Within this context, however, some of key island issues relating to their peripherality and competitiveness vis-à-vis the European mainland are only indirectly addressed. This research suggests that these two additional impact issues be added to the EU's list of impact issues.

Research into policy-designing and policy-making within EU institutions, has indicated that EU island states, particularly Malta, have attempted to get island sustainable concerns incorporated within the EU's legislative framework. In selected instances, as for Directive $2008 / 101$ and common immigration policy, this has been successful; with the accession to the EU of Malta and Cyprus, island issues have acquired more relevance. Further research is however required to identify all the areas where island sustainability issues may not yet be taken sufficiently into account in EU policy-making and policy design.

This study has faced a major constraint relating to the lack of statistical data on sustainability issues for European islands, mainly due to the fact that they are often classified at NUTS-1 or 2. This constraint is complicated by lack of harmonization of data for the different islands. A major finding of this survey, also raised in Planistat (2002), concerns the need to develop comparable datasets on these issues, which may be used to inform policy decisions at EU level regarding the sustainable development of island regions. It is hoped that this survey will raise the profile of island sustainability in Europe, which will in turn influence the EU policy-making process, and thus the progress of sustainable development in European islands.

A growing number of studies have contributed towards greater understanding of sustainability issues in islands, but this remains a relatively new area of research in the European context. This places the present research in an arena of innovation where island sustainability concepts need to be adapted to a European context, and studies from a political economy perspective need to be adapted to take sustainability into account.

\section{Acknowledgements}

This paper is a revised and updated version, from the same authors, of a paper published in Anuario Do Centro De Estudos de Historia Do Atlantico, Nr. 1, 2009, ISSN 1647-3949. Centro de Estudos de Historia do Atlantico: Madeira, and originally entitled 'Islands at the Periphery: Integrating the Challenges of Island Sustainability into European Policy'. Acknowledgements are due to the 26 experts who kindly consented to be interviewed in this survey, and to the many contacts in the various island networks who put the authors in touch with them. Thanks are also due to the FP6 program the European Commission and 
all the SENSOR partners who contributed to the overall research activities. The 'small island jurisdiction' database, moderated by the University of Prince Edward Island, Canada, was also kindly available for this study. We also thank Prof. Lino Briguglio for ongoing advice and the use of the University of Malta's Islands and Small States Institute library, MEPA's staff and university students and to the Rural Development Department within the then Ministry for Rural Affairs \& Environment (MRAE), Government of Malta.

The research on which this paper is based was carried out within the framework of the European FP6 project SENSOR, on science-based ex-ante Sustainability Impact Assessment Tools (SIAT) to support decision making on policies related to multifunctional land use in European regions ('Sustainability Impact Assessment: Tools for Environmental, Social and Economic Effects of Multifunctional Land Use in European Regions' (SENSOR), Contract Number 003874.

\section{References}

Arnell, N., Tompkins, E., Adger, N. \& Delaney, K. (2005) Vulnerability to Abrupt Climate Change in Europe. Tyndall Centre Technical Report No. 34, Norwich, University of East Anglia, www.tyndall.ac.uk/sites/default/files/tr34.pdf.

Baldacchino, G. \& Milne, D. (eds.) (2000) Lessons from the Political Economy of Small Islands: The Resourcefulness of Jurisdiction, Basingstoke, Macmillan.

Bayliss-Smith, T., Bedford, R., Brookfield, H.C. \& Latham, M. (1988) Islands, Islanders and the World: The Colonial and Post-colonial Experience in Eastern Fiji, Cambridge, Cambridge University Press.

Briguglio, L. \& Cordina, G. (2004) Competitiveness Strategies for Small States. Malta, Islands and Small States Institute of the University of Malta.

Briguglio, L. (1995) 'Small Island Developing States and their Economic Vulnerabilities', World Development, Vol. 23, No. 9, pp. 1615-1632.

Briguglio, L. (2004) Economic Vulnerability and Resilience: Concepts and Measurements, paper presented at international workshop on vulnerability and resilience of small states, Gozo, Malta, 2004.

Briguglio, L., Cordina, G. \& Eliawony, K. (2006) Building the Economic Resilience of Small States, Malta and London, Islands and Small States Institute, University of Malta and the Commonwealth Secretariat.

Briguglio, L. (1993) The Economic Vulnerabilities of Small Island Developing States, study commissioned by CARICOM for Regional Technical Meeting of the Global Conference on the Sustainable Development of Small Island Developing States, Port of Spain, Trinidad and Tobago, July. 
CEC (1994) Eurostat: Portrait of the Islands, Luxembourg, Office of the Official Publications of the European Communities.

CEC (2001) A Sustainable Europe for a Better World: A European Union Strategy for Sustainable Development, COM (2001) 264, Brussels.

CEC (2005) Impact Assessment Guidelines, 15 June, SEC (2005) 791, Brussels.

Central Statistics Office Ireland (2006) http://www.cso.ie.

Committee of the Regions (CoR) (2002) Opinion of the Committee of the Regions of 13 March 2002 on the Problems of Island Regions in the European Union in the Context of Enlargement, lex.europa.eu/LexUriServ/site/en/oj/2002/c_192/c_19220020812en00420045.pdf.

Conference of the Representatives of the Governments of the Member States (2007) Draft Declarations IGC 03/07, www.consilium.europa.eu/uedocs/cmsUpload/cg00003.en07.pdf.

Cordina, G. \& Farrugia, N. (2005) Measuring Vulnerability: A Methodological Review and a Refinement based on Partner Country and Price Volatility Issues, Occasional Paper No. 4, Malta, Foundation for International Studies, University of Malta.

Economic and Social Committee (ECOSOC) (2000) Opinion of the Economic and Social Committee on Guidelines for Integrated Actions on the Island Regions of the European Union following the Amsterdam Treaty (Article 158). http://eurlex.europa.eu/LexUriServ/site/en/oj/2000/c_268/c_26820000919en00320038.pdf.

Eurisles (1997) Statistical Indicators of Regional Disparities generated by Insularity and Ultraperipherality. Ajaccio, Corsica, Eurisles.

Eurisles (2002) Off the Coast of Europe: European Construction and the Problem of the Islands, Ajaccio, Corsica, Eurisles on the initiative of the Islands Commission of CPMR (Conference of the Peripheral and Maritime Regions).

European Commission (2005) Impact Assessment Guidelines, SEC(2005) 791, www.letgroup.com/iss10/iss.nsf/ae76a4ee10890d4bc1256fb9005f74fe/b70957044a280002c12576e 5007f2967/\$FILE/CEC_Impact_Assessment_Guidelines_2005.pdf.

European Commission (2006) Commission staff working document accompanying document to the Proposal for a Directive of the European Parliament and of the Council amending Directive 2003/87/EC so as to include aviation activities in the scheme for greenhouse gas emission allowance trading within the Community: Impact Assessment of the inclusion of aviation activities in the scheme for greenhouse gas emission allowance trading within the Community, SEC (2006) 1684, Brussels. 
European Council (2004) Treaty Establishing a Constitution for Europe. Official Journal C310. http://eur-lex.europa.eu/JOHtml.do?uri=OJ:C:2004:310:SOM:EN:HTML.

European Council (2006a) Council Regulation (EC) No 1198/2006 of 27 July 2006 on the European Fisheries Fund, http://eurlex.europa.eu/LexUriServ/LexUriServ.do?uri=OJ:L:2006:223:0001:0044:EN:PDF.

European Council (2006b) Review of the EU Sustainable Development Strategy (EU SDS) Renewed Strategy, COM http://ec.europa.eu/sustainable/docs/renewed eu_sds_en.pdf.

European Environment Agency (EEA) (2005) The European Environment: State and Outlook 2005, Copenhagen, EEA.

European Environmental Agency (EEA) (2006) Integration of Environment into EU Agriculture Policy: The IRENA Indicator-based Assessment Report, Copenhagen, EEA.

European Parliament. Busuttil, S. (2009a) Draft Report on a Common Immigration Policy for Europe: Principles, Actions and Tools (2008/2331 INI) - presented in the Civil Liberties Committee (LIBE) at the European Parliament on the $11^{\text {th }}$ of February 2009. Brussels.

European Parliament. Busuttil, S. (2009b) Parliamentary Answer E-2763/09. Brussels.

European Parliament. Busuttil, S. (2009c) Parliamentary Question E-2163/06. Brussels.

European Parliament. Viola V. (1998) Report on the Problems of Island Regions in the European Union, Committee on Regional Policy. Brussels.

Eurostat (2006) European Commission Statitics Office, http://ec.europa.eu/eurostat/.

Fundacion Natura, www.fnatura.org/.

Global Islands Network www.globalislands.net/.

Govern de Les Illes Balears (2006) www.caib.es/

Hein P.L. (2004) Is Special Treatment of Small Island Developing States Possible?, Geneva and New York, United Nations Conference on Trade and Development, http://www.unctad.org/en/docs/ldc20041_en.pdf.

Highlands and Islands Enterprise (2006) www.hie.co.uk.

Iceland on the Web (2006) http://iceland.vefur.is.

Instituto Nacional de Estadística (2006) www.ine.es/en/welcome_en.htm. 
Insula (2006) International Scientific Council for Island Development, www.insula.org/.

Islands Commission (2000) What Status for Europe's Islands? Paris, Editions l'Harmattan for CPMR.

IslandStudies.ca (2005-06) www.islandstudies.ca/.

Istat.it (2006) Istituto Nazionale di Statistica, Italy, www.istat.it/.

IUCN (2006) International Union for the Conservation of Nature, www.iucn.org/.

Levine, N.L. (2002) CrimeStat: A Spatial Statistics Program for the Analysis of Crime Incident Locations (v. 2.0), Houston TX and Washington DC, Ned Levine \& Associates and the National Institute of Justice.

Metz, B. (2001) Climate Change 2001: Impacts, Adaptation and Vulnerability: Contribution of Working Group II to the 3rd Assessment Report of the Intergovernmental Panel on Climate Change, Cambridge, Cambridge University Press.

Musotto, F. (2007) Report on the Islands and Natural and Economic Constraints in the Context of the Regional Policy. A6-0044/2007, European Parliament, Committee on Regional Development.

Planistat Europe (2002) Analyse des régions insulaires de l'Union Européenne (Survey of insular regions of the EU). In Interreg Project, DG Regio, Brussels, European Commission.

SENSOR (2007) www.sensor-ip.eu.

Small Island Developing States Network (2003) To Know All About Small Island Developing States, www.sidsnet.org/.

Tyndall Centre for Climate Change Research (2005) Surviving Climate Change in Small Islands: A Guidebook, Norwich, University of East Anglia.

United Nations (UN) (1994) Programme of Action for Small Island States. Proceedings of the Global Conference on the Sustainable Development of Small Island Developing States. Bridgetown, Barbados, http://www.un-documents.net/sids-act.htm.

United Nations (UN) (2002) World Summit on Sustainable Development: Plan of Implementation, New York, United Nations.

United Nations (UN) (2003) Statistics Pocketbook: Small Island Developing States, New York, Department of Economic and Social Affairs, Statistics Division. 
United Nations (UN) (2006) www.un.org/.

Wells, J. (1996) Composite Vulnerability Index: A Preliminary Report, London, Commonwealth Secretariat. 